\title{
ANÁLISE DA RESPIRAÇÃO, ATIVIDADE ENZIMÁTICA E CONTAGEM DAS BACTÉRIAS MESÓFILAS EM SOLO IMPACTADO COM FUNGICIDA
}

\author{
Letícia Aparecida Costa ${ }^{1}$; Bruno Magro Rodrigues ${ }^{1}$; Fábio Fernando de Araújo ${ }^{2}$ \\ ${ }^{1}$ Curso de Graduação em Engenharia Ambiental - Faculdade de Engenharia de Presidente Prudente/UNOESTE. ${ }^{2}$ \\ Docente da Universidade do Oeste Paulista - UNOESTE. E-mail: le_costa93@hotmail.com
}

\section{RESUMO}

O Fungicida Tetraconazol é uma substância que inibe os fungos, para controlar alguns tipos de doenças em plantas, no presente trabalho ele foi utilizado para contaminar o solo, e através disso avaliarmos alguns parâmetros como a respiração do solo, a atividade enzimática e a contagem das bactérias. O solo é composto por uma infinidade de seres vivos e quando o impactamos ele responde a esse estímulo de diversas formas.

O presente trabalho objetivou analisar a respiração do solo, a atividade enzimática, e verificar a presença de microrganismos através da contagem de bactérias mesófilas em função da introdução do fungicida tetraconazol no solo.

Palavras-chave: Microbiologia, Agricultura, Poluição do Solo, Impacto Ambiental, Indicadores microbiológicos.

\section{INTRODUÇÃO}

Com a finalidade de compreender melhor o funcionamento do solo e de toda a composição microbiana contida no mesmo, são realizados estudos que possibilitam que se tenha melhoria nas atividades que o envolva.

De acordo com Machado (2012), o solo é constitui-se por um grande número de seres vivos microscópicos. Uma colher de chá do solo fértil de um jardim pode conter bilhões de microrganismos. A flora microbiana caracteriza-se pela sua abundância e diversidade.

Os microrganismos aumentam a fertilidade do solo pela conversão (fixação), do nitrogênio atmosférico em compostos nitrogenados, utilizados pelas plantas na síntese de proteínas. Convertem as substâncias orgânicas em compostos inorgânicos, tornando-os úteis para os vegetais. Aceita-se que os micro-organismos decompõem os vegetais e animais mortos, mas não é possível imaginar, às vezes que as reações bioquímicas realizadas fertilizam o solo pelo fornecimento de nutrientes. Este é um processo complexo, do qual participam muitos tipos de microrganismos. Calcula-se que 0,4 há de solo fértil contém cerca de $500 \mathrm{~kg}$ de bactérias e talvez, quantidades equivalentes de fungos, protozoários e algas. É uma verdade generalizada que, quanto mais micro-organismos existirem no solo, mais produtivo ele será (MACHADO, 2012). 
É possível utilizar a atividade enzimática para detectar mudanças que ocorrem no solo, em virtude do sistema de manejo e da sua incorporação a atividade agrícola. As enzimas são proteínas especializadas na catálise de reações biológicas. Elas estão entre as biomoléculas mais notáveis devido a sua extraordinária especificidade e poder catalítico, que são muito superiores aos dos catalisadores produzidos pelo homem. Praticamente todas as reações que caracterizam o metabolismo celular são catalisadas por enzimas (MENDES; REIS JUNIOR; NETO, 2012).

O fungicida foi a substância usada para impactar o solo, ele é um pesticida que destrói ou inibe a ação dos fungos que geralmente atacam as plantas.

A utilização de fungicidas sintéticos é muito comum na agricultura convencional, e por se tratar de um produto tóxico representa um risco potencial ao homem e ao meio-ambiente. Já na agricultura alternativa, ou agricultura orgânica, o controle dos fungos é realizado utilizando-se produtos naturais e com técnicas de manejo alternativas (GRUPO DE PROCESSOS BIOTECNOLÓGICOS, 2003).

Todos aqueles que desejam utilizar fungicidas para controlar doenças de vegetais devem se atentar às exigências de menor risco á saúde humana e ao meio ambiente (ZAMBOLIM, 2008).

Segundo Fonseca (2012), no solo também encontramos além dos fungos, as bactérias que são organismos unicelulares com tamanho microscópico, medindo cerca de 0,2 a 1,5 $\mu \mathrm{m}$ de comprimento.

As bactérias representam a maior parte da comunidade microbiana do solo tanto em quantidade como em variedade. As bactérias mesófilas apresentam crescimento ótimo em temperaturas variando entre $25{ }^{\circ} \mathrm{C}$ e $40^{\circ} \mathrm{C}$, ou seja, a faixa de temperatura mais comum na superfície da Terra e nos organismos animais (PUC GOIÁS, 2012).

O experimento foi realizado com a finalidade de se obter resultados que mostrem o nível de impacto causado em um solo contaminado por diferentes tipos de substâncias.

\section{OBJETIVO}

O objetivo desse trabalho é analisar a respiração do solo, a atividade enzimática e verificar a presença de microrganismos através da contagem de bactérias mesófilas em função da introdução do fungicida tetraconazol no solo. 


\section{METODOLOGIA}

Realizou-se o experimento entre os meses de Setembro à Novembro do dia 10/09 ao dia 06/11 de 2012 na Universidade do Oeste Paulista, Presidente Prudente- SP.

Esse experimento teve início do dia 10/09/12, onde se reservou uma área de solo em área aberta com as dimensões de $50 \times 50 \mathrm{~cm}$, onde foi colocada a substância Fungicida Tetraconazol com concentração de $20 \mathrm{~m}^{3} /$ ha, ou $0,5 \mathrm{~L} / 0,25 \mathrm{~m}^{2}$.

No dia do experimento o solo estava muito seco, molhou-se um pouco com água, em seguida na área reservada foi colocado o Fungicida Tetraconazol. Cobriu-se a área com um plástico, em seguida foi feito um furo e colocou-se uma mangueira plástica ligada a um tubo de vidro com uma rolha na ponta, com um erlenmeyer contendo $100 \mathrm{ml}$ de $\mathrm{NaOH}$. Esta solução coletou o $\mathrm{CO}_{2}$ produzido no local.

No dia que se levou o erlenmeyer, foi fechado com a rolha e papel alumínio, e levado ao laboratório.

Repetiu-se o procedimento por sete semanas, em um dia colocava o erlenmeyer e no outro retirávamos para medir a respiração do solo.

No laboratório dia 22/10/2012 preparou-se placas para realizar a contagem das bactérias aeróbicas mesófilas em amostras de solo, tendo-se como objetivo verificar a presença de microrganismos em amostras de solo através do método direto (contagem). Depois de uma semana no dia 29/10/2012 foi realizada a contagem dos microrganismos na placa.

No dia 05/11/2012 foi realizada a quantificação da atividade de enzima desidrogenase, de acordo com o método do tetrazólio e realizada a leitura com o espectrofotômetro em 530 nm no dia seguinte após 18 horas.

Os dados obtidos foram analisados e apresentados na forma de gráficos e tabelas.

\section{RESULTADOS}

Após a introdução do Fungicida Tetraconazol a respiração do solo teve um comportamento descrito na Figura 1. 


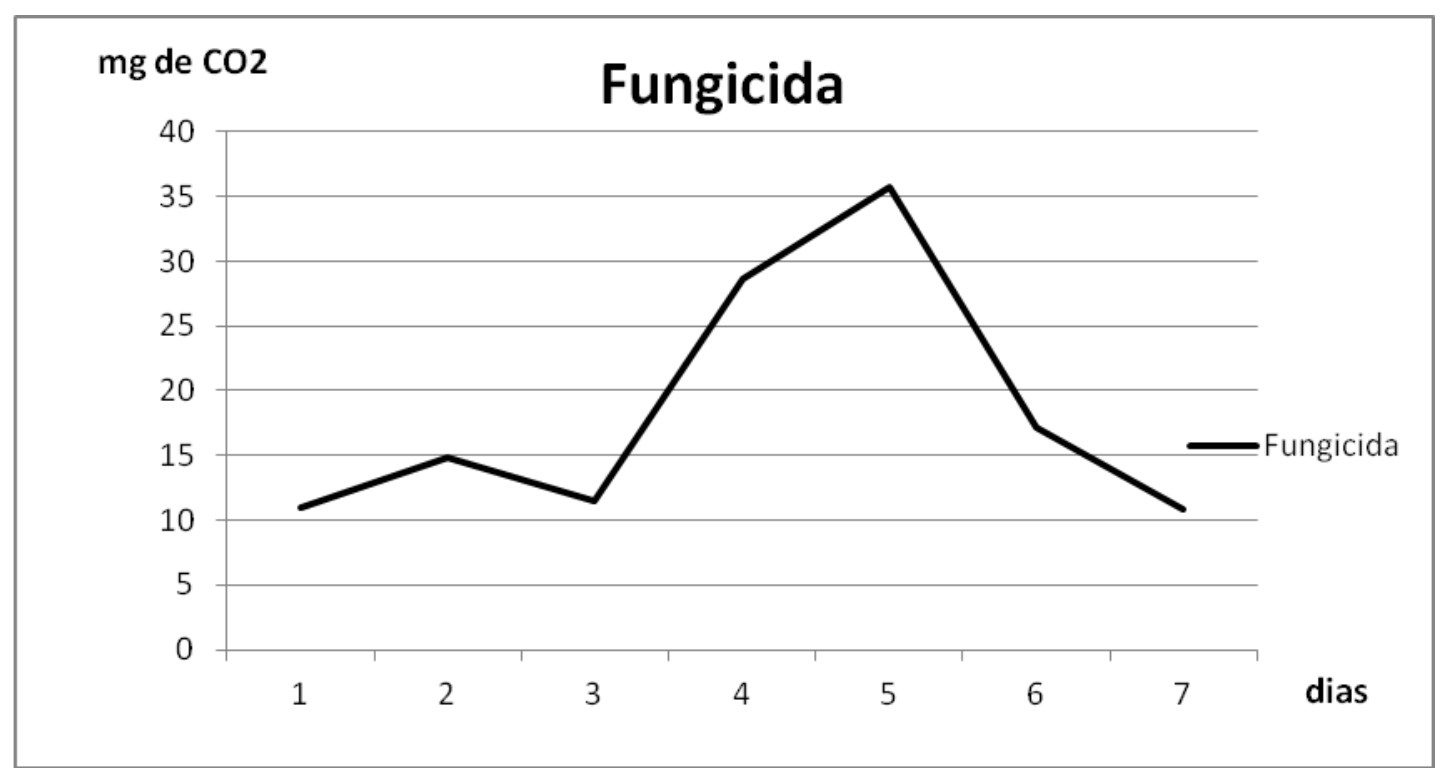

Figura 1. Comportamento da respiração do solo com Fungicida durante 7 dias.

A Tabela 1 mostra os resultados da presença de bactérias mesófilas e atividade enzimática no solo em estudo.

Tabela 1. Avaliação de bactérias mesófilas e atividade enzimática em solos impactados.

\begin{tabular}{|llll|}
\hline Tratamento & $\begin{array}{c}\text { No de bactérias/ } \\
\text { de solo }\end{array}$ & \% de diversidade & $\begin{array}{c}\text { Leitura } \\
\text { (espectrofotômetro) } \\
\text { em } \mathbf{5 3 0} \text { nm }\end{array}$ \\
\hline Fungicida & $1,5-10^{\wedge} 5$ & $66 \%$ & 0,290 \\
\hline Controle & $5 \times 10^{\wedge} 5$ & $0 \%$ & 0,660 \\
\hline
\end{tabular}

\section{DISCUSSÃO}

Através de análise da quantidade de $\mathrm{CO}_{2}$ (respiração), percebeu-se que o solo teve um comportamento diferente em cada época, nas primeiras semanas os microrganismos não conseguiram decompor em grande escala a substância que estava impactando o solo, neste caso o Fungicida Tetraconazol, mas a partir da 3a semana os microrganismos começaram a responder melhor, pois a quantidade de $\mathrm{CO}_{2}$ aumentou significativamente.

A quantidade de $\mathrm{CO}_{2}$ nos mostra a respiração do solo, pois quanto mais $\mathrm{CO}_{2}$, mais degradado está à matéria orgânica no solo, e quanto menos $\mathrm{CO}_{2}$ representa que os microrganismos não estão decompondo aquele material. Analisar a respiração do solo é de extrema importância, pois os microrganismos garantem a qualidade do solo. 
Podemos perceber que o resultado do controle da atividade enzimática foi superior se comparado com a nossa amostra de Fungicida, isso nos mostra que quando o solo é contaminado as enzimas não conseguem desempenhar a mesma função de um solo não impactado.

Em todos os kg de solo fértil tem-se em média 500 bilhões de bactérias e 1 bilhão de fungos. Na contagem das bactérias nas placas percebemos que o solo possuía $66 \%$ de diversidade, na placa com diluição de $10^{5,}$ e $100 \%$ na placa de $10^{6}$, portanto, o crescimento bem sucedido de uma comunidade de bactérias reflete seu grau de adaptação.

\section{CONCLUSÃO}

Conclui-se que o solo impactado com Fungicida Tetraconazol sofre alterações, prejudicando alguns processos naturais do solo.

Quando analisamos a respiração do solo podemos notar que não foi regular, em algumas semanas a quantidade de $\mathrm{CO}_{2}$ foi baixo isso significa os microrganismos não conseguiram decompor adequadamente a matéria orgânica.

A atividade enzimática é prejudicada com o solo contaminado, visto que a amostra que foi analisada onde não foi adicionada nenhuma subtância teve uma atividade enzimática maior.

$\mathrm{Na}$ contagem das bactérias podemos perceber que a interferência do Fungicida Tetraconazol não foi tão negativa, pois o Fungicida ataca os fungos, e não as bactérias, então elas se mantiveram mesmo com o solo impactado.

\section{REFERÊNCIAS}

FONSECA, Krukemberghe. Bactérias. Brasil Escola. Disponível em: <http://www.brasilescola.com/biologia/bacterias.htm>. Acesso em: 21 out. 2012.

GRUPO DE PROCESSOS BIOTECNOLÓGICOS. Enzimas. Florianópolis: Universidade Federal de Santa Catarina - Departamento de Engenharia Química e Engenharia de Alimentos. Disponível em: <http://www.enq.ufsc.br/labs/probio/disc_eng_bioq/trabalhos_pos2003/const_microorg/enzima s.htm>. Acesso em: 21 out. 2012.

MACHADO, Alberto. A importância da bactéria no Solo. Momento Agronomia. Disponível em: <http://momentoagronomia.blogspot.com.br/p/importancia-da-bacteria-no-solo.html>. Acesso em: 21 out. 2012.

MENDES, leda de Carvalho; REIS JUNIOR, Fabio Bueno dos; NETO, João Vicente. Distribuição da atividade enzimática no perfil de um latossolo vermelho amarelo de cerrado sob vegetação nativa e sob sistemas de plantio direto e convencional. EMBRAPA CERRADOS. Disponível em: <www.cpac.embrapa.br/download/913/t>. Acesso em: 19 out. 2012. 
PUC GOIÁS. Crescimento populacional de bactérias. Disponível em: <http://professor.ucg.br/siteDocente/admin/arquivosUpload/3909/material/Crescimento\%20Pop ulacional\%20de\%20Bact\%C3\%A9rias.pdf>. Acesso em: 19 out. 2012.

VIANA, Laci Guimarães. Ação de diferentes temperaturas sobre os microorganismos. Rio de Janeiro: Instituto federal de educação, ciência e tecnologia fluminense, 2010. Disponível em: <http://www.ebah.com.br/content/ABAAAAxOUAA/relatorio-microbiologia>. Acesso em: 21 out. 2012.

ZAMBOLIM, L et al. Produtos fitossanitários. (fungicidas, inseticidas, acaricidas e herbicidas). Viçosa: UFV/DFP, 2008. 